Pacific Journal of Mathematics

CONSTANT MEAN CURVATURE SURFACES ON A STRIP 


\title{
CONSTANT MEAN CURVATURE SURFACES ON A STRIP
}

\author{
AI NUNG WANG
}

For bounded planar domains there is a notion of extremal domain for which the constant mean curvature equation $\operatorname{div}\left(D u / \sqrt{1+|D u|^{2}}\right)$ $=2$ has a unique solution under no boundary conditions whatsoever. Extending to unbounded domains, it was expected that an infinite strip of unit width has the analogous property of admitting only cylinders as solutions. We show here that in fact other (distinct) solutions can appear.

The idea is to construct a super-solution $\operatorname{div}\left(D v / \sqrt{1+|D v|^{2}}\right)<2$ and a subsolution $w \leq v$ with the same boundary values on the strip $\Omega=\left\{(x, y) \mid-\frac{1}{2} \leq y \leq \frac{1}{2}\right\}$. Implicitly we describe the function $w=w(x, y)$ by a parametric surface

$$
\begin{aligned}
& x=\xi-\frac{1}{2}(1-\cos \theta) \frac{\xi}{\sqrt{1+\xi^{2}}}, \\
& y=\frac{1}{2} \sin \theta, \\
& z=\frac{1}{2} \xi^{2}+\frac{1}{2}(1-\cos \theta) \frac{1}{\sqrt{1+\xi^{2}}},
\end{aligned}
$$

which is a parabolic trough with semi-circular cross section. Clearly its mean curvature $>2$ and a moment reflection shows that it is a graph. Also the two boundary curves are congruent and have curvature $\leq 1$. Therefore the parabolic cylinder containing these two curves is the required super-solution $v$.

The author would like to express his gratitude to Mr. Jenn-Fang Hwang for bringing this problem to his attention.

\section{REFERENCES}

For an affirmative result under extra boundary condition, the reader is referred to:

Luen-Fai Tam, On the Uniqueness of Capillary Surfaces, in Variational Methods for Free Surface Interfaces (P. Concus \& R. Finn, eds.), Springer-Verlag, 1987. 
For the existence of a constant mean curvature surface in between a sub-solution and a super-solution, the reader is referred to:

Enrico Giusti, Minimal Surfaces and Functions of Bounded Variation, Birkhäuser, 1984.

Received September 26, 1988. Partially supported by Grant NSC 79-0208-M002-19.

NATIONAL TAIWAN UNIVERSITY

TAIPEI, TAIWAN, R.O.C. 


\title{
PACIFIC JOURNAL OF MATHEMATICS EDITORS
}

\author{
V. S. VARADARAJAN \\ (Managing Editor) \\ University of California \\ Los Angeles, CA 90024-1555-05 \\ Herbert Clemens \\ University of Utah \\ Salt Lake City, UT 84112 \\ ThOMAS ENRIGHT \\ University of California, San Diego \\ La Jolla, CA 92093
}

R. FINN

Stanford University

Stanford, CA 94305

HeRmanN FlaschKa

University of Arizona

Tucson, AZ 85721

VAUGHaN F. R. Jones

University of California

Berkeley, CA 94720

Steven Kerckhoff

Stanford University

Stanford, CA 94305

\section{C. MOORE}

University of California

Berkeley, CA 94720

MaRTin SCHARLEMANN

University of California

Santa Barbara, CA 93106

HAROLD STARK

University of California, San Diego

La Jolla, CA 92093

\section{ASSOCIATE EDITORS}
R. ARENS
E. F. BECKENBACH (1906-1982)
B. H. NeumanN
F. WOLF
(1904-1989)
K. YosHidA

\section{SUPPORTING INSTITUTIONS}

UNIVERSITY OF ARIZONA
UNIVERSITY OF BRITISH COLUMBIA
CALIFORNIA INSTITUTE OF TECHNOLOGY
UNIVERSITY OF CALIFORNIA
MONTANA STATE UNIVERSITY
UNIVERSITY OF NEVADA, RENO
NEW MEXICO STATE UNIVERSITY
OREGON STATE UNIVERSITY
UNIVERSITY OF ARIZONA
UNIVERSITY OF BRITISH COLUMBIA UNIVERSITY OF CALIFORNIA
MONTANA STATE UNIVERSITY
NEW MEXICO STATE UNIVERSITY

\author{
UNIVERSITY OF SOUTHERN CALIFORNIA \\ STANFORD UNIVERSITY \\ UNIVERSITY OF HAWAII \\ UNIVERSITY OF TOKYO \\ UNIVERSITY OF UTAH \\ WASHINGTON STATE UNIVERSITY \\ UNIVERSITY OF WASHINGTON
}
UNIVERSITY OF OREGON

The Supporting Institutions listed above contribute to the cost of publication of this Journal, but they are not owners or publishers and have no responsibility for its content or policies.

\begin{abstract}
Mathematical papers intended for publication in the Pacific Journal of Mathematics should be in typed form or offset-reproduced (not dittoed), double spaced with large margins. Please do not use built up fractions in the text of the manuscript. However, you may use them in the displayed equations. Underline Greek letters in red, German in green, and script in blue. The first paragraph must be capable of being used separately as a synopsis of the entire paper. In particular it should contain no bibliographic references. Please propose a heading for the odd numbered pages of less than 35 characters. Manuscripts, in triplicate, may be sent to any one of the editors. Please classify according to the 1980 Mathematics Subject Classification (1985 Revision) scheme which can be found in the December index volumes of Mathematical Reviews. Supply name and address of author to whom proofs should be sent. All other communications should be addressed to the managing editor, or Elaine Barth, University of California, Los Angeles, California 90024-1555-05.

There are page-charges associated with articles appearing in the Pacific Journal of Mathematics. These charges are expected to be paid by the author's University, Government Agency or Company. If the author or authors do not have access to such Institutional support these charges are waived. Single authors will receive 50 free reprints; joint authors will receive a total of 100 free reprints. Additional copies may be obtained at cost in multiples of 50 .
\end{abstract}

The Pacific Journal of Mathematics (ISSN 0030-8730) is published monthly. Regular subscription rate: $\$ 190.00$ a year (12 issues). Special rate: $\$ 95.00$ a year to individual members of supporting institutions.

Subscriptions, orders for numbers issued in the last three calendar years, and changes of address should be sent to Pacific Journal of Mathematics, P.O. Box 969, Carmel Valley, CA 93924, U.S.A. Old back numbers obtainable from Kraus Periodicals Co., Route 100, Millwood, NY 10546.

The Pacific Journal of Mathematics at P.O. Box 969, Carmel Valley, CA 93924 (ISSN 0030-8730) is published monthly. Second-class postage paid at Carmel Valley, California 93924, and additional mailing offices. Postmaster: send address changes to Pacific Journal of Mathematics, P.O. Box 969, Carmel Valley, CA 93924.

\section{PUBLISHED BY PACIFIC JOURNAL OF MATHEMATICS, A NON-PROFIT CORPORATION}




\section{Pacific Journal of Mathematics}

Vol. 145, No. $2 \quad$ October, 1990

Chong Hsio Fang and Minking Eie, On the values of a zeta function at

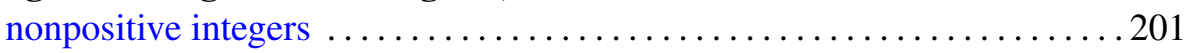

Howard D. Fegan, Brian F. Steer and L. Whiteway, Spectral symmetry of the Dirac operator for compact and noncompact symmetric pairs ..... 211

William James Heinzer and David C. Lantz, Integral domains that lose

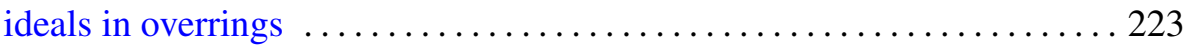

Alexander Eben Koonce, Relations among generalized characteristic classes .......................................239

M. S. Narasimhan and Günther Trautmann, Compactification of

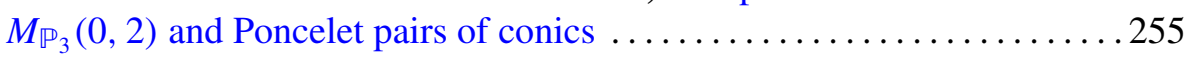

James Alexander Reeds, III and Lawrence A. Shepp, Optimal paths for a car that goes both forwards and backwards . ................. 367

Ai-Nung Wang, Constant mean curvature surfaces on a strip ............ 395 